coverts, primary quills, and outer secondaries brownish-black, very narrowly margined with brownish-white. Tail greyish-blue at the base, much paler and tinged with yellow toward the end, these colours being separated at the distance of two inches from the tip by a band of black.

Length to end of tail 16 inches, to end of wings $13 \frac{3}{4}$; wing from flexure 9; tail $6 \frac{1}{4}$; bill along the ridge $\frac{10}{12}$, along the edge of lower mandible $1 \frac{1}{12}$; tarsus $1 \frac{1}{12}$; hind toe $\frac{8}{12}$, its claw $\frac{5}{1 \frac{1}{2}}$; middle toe $1 \frac{4 \frac{1}{2}}{12}$, its claw $\frac{7}{12}$.

Adult Female.

The female differs from the male only in having the tints a little duller, and on the upper parts somewhat darker, with the black band on the tail less decided, the middle feathers being but faintly marked with it.

Length to end of tail $15 \frac{1}{2}$ inches.

\title{
NutTall's Dog-Wood.
}

\section{Cornus Nuttalli, Audubon.}

This very beautiful tree, which was discovered by Mr. Nutrall on the Columbia river, attains a height of fifty feet or more, and is characterized by its smooth reddish-brown bark; large, ovate, acuminate leaves, and conspicuous flowers, with six obovate, acute, involucral bracteas, which are rosecoloured at the base, white towards the end, veined and reticulated with light purple. The berries are oblong, and of a bright carmine.

\section{WHITE-HEA DED DOVE, OR PIGEON.}

\section{+ Columba leucocephala, Linn.}

\section{PLATE CCLXXX.-Male and Female.}

The White-headed Pigeon arrives on the Southern Keys of the Floridas, from the Island of Cuba, about the 20th of April, sometimes not until the 1st of May, for the purpose of residing there for a season, and rearing its young. On the 30th of April, I shot several immediately after their arrival from across the Gulf Stream. I saw them as they approached the shore, 
skimming along the surface of the waters, flying with great rapidity, much in the manner of the common house species, but not near each other like the Passenger Pigeon. On nearing the land, they rose to the height of about a hundred yards, surveyed the country in large circles, then with less velocity gradually descended, and alighted in the thickest parts of the mangroves and other low trees. None of them could be easily seen in those dark retreats, and we were obliged to force them out, in order to shoot them, which we did at this time on the wing.

In creeping among the bushes to obtain a view of them whilst alighted, I observed that the more I advanced, the more they retired from me. This they did by alighting on the ground from the trees, among which they could not well make way on wing, although they could get on with much ease below, running off and hiding at every convenient spot that occurred. These manœuvres lasted only a few days, after which I could see them perched on the tops of the trees, giving a preference perhaps to dry branches, but not a marked one, as some other species are wont to do.

They are at all times extremely shy and wary, more so in fact than any species with which I am acquainted. The sight of a man is to them insupportable, perhaps on account of the continued war waged against them, their flesh being juicy, well flavoured, and generally tender, even in old birds. Never could I get near one of them so long as it observed me. Indeed, the moment they perceive a man, off they go, starting swiftly with a few smart raps of the wings, and realighting in a close covert for awhile, or frequently flying to another key, from which they are sure to return to that left by them, should you pursue them. It is thus a most toilsome task to procure specimens of these birds.

Their shyness is but partially given up even during their love season, or while sitting on their eggs, for the moment they see you they get off slyly from the nest, walk on the branches for some distance, and take to wing without any noise, flying low along the edge of the mangroves, into which they throw themselves as soon as a place of safety offers itself, seldom on such occasions flying off to other keys. Their return to the nest is not immediate, the heat of these latitudes not requiring the same care in incubation as the comparative cold of more northern regions. I have waited their return sometimes as much as half an hour, without success.

By the first of May, the young squabs are nearly able to fly, and it is at this period that the greatest havoc is made among them. The fishermen and the wreckers visit the keys principally resorted to by this species, rifle all the nests they can find, and sometimes also shoot the old birds.

The key on which I first saw this bird, lies about twenty-five miles south of Indian Key, and is named Bahia-honda Duck Key. The farther south 
we proceeded the more we saw, until we reached the low, sandy, sterile keys, called the Tortugas, on none of which did I see a Pigeon of any kind. During my visit to the Floridas, our party procured a great number of White-headed Pigeons. They were all either adult or full-plumed birds, having the upper part of the head pure white, with a deep rich brown edging at the lateral parts of the crown. On our return from the Tortugas to Key West, our vessel anchored close to a small key, in a snug harbour protected from the sea winds by several long and narrow islands well known to the navigators of those seas. Captain $\mathrm{D}_{\mathrm{AX}}$ and myself visited this little key, which was not much more than an acre in extent, the same afternoon. No sooner had we landed, than, to our delight, we saw a great number of Whiteheaded Pigeons rise, fly round the key several times, and all realight upon it. The Captain posted himself at one end of the key, I at the other, while the sailors walked about to raise the birds. In less than two hours we shot thirty-six of them, mostly on the wing. Their attachment to this islet resulted from their having nests with eggs on it. Along with them we found Grakles, Red-winged Starlings, Flycatchers, and a few Zenaida Doves. Having shot most of the Pigeons, examined their nests, collected their eggs, and written memoranda, we proceeded to other keys in search of other species.

The next morning we thought of calling at this little key on our way, and were surprised to find that many new comers had arrived there before us. They were, however, very shy, and we procured only seventeen in all. I felt convinced that this spot was a favourite place of resort to these birds. It being detached from all other keys, furnished with rank herbaceous plants, cactuses, and low shrubs, and guarded by a thick hedge of mangroves, no place could be better adapted for breeding; and, at each visit we paid it, White-headed Pigeons were procured. Allow me here, kind reader, to tell you that the number of that strange species of crabs called soldiers was so great, that our game could not be suffered to lie a few minutes on the ground without being either much mangled or carried into their subterranean retreats; so that, with all our care, we were actually deprived by them of several birds which we had shot. These curious crabs, which belong to the genus Pagurus, crawl up the trees, and no doubt often destroy the eggs or young of the Pigeons.

The principal difference between Pigeons and Doves, as to their habits, is, according to my observation, that the former generally build their nests close together on the same trees, which the latter never do. For this reason I place the present species among the Doves.

The nest is placed high or low, according to circumstances; but there are never two on the same tree. I have found it on the top shoots of a cactus, 
only a few feet from the ground, on the upper branches of a mangrove, or quite low, almost touching the water, and hanging over it. In general the nest resembles that of the Columba migratoria, but it is more compact, and better lined. The outer part is composed of small dry twigs, the inner of fibrous roots and grasses. The eggs are two, opaque, white, rather roundish, and as large as those of the domestic Pigeon. From the appearance of the eggs in the ovaria of females having young at the time, I would infer that this species has several broods during each season; and perhaps they may breed in Cuba, after their return from the Florida Keys. None of these birds are found on the mainland, although it is at no great distance.

A rather extraordinary fact relating to the habits of this species, is that many of these birds, which breed in Cuba, or some of the Bahama Islands, come to the Florida Keys for the purpose of procuring food for their young, to which they return several times daily. This is particularly observed at the time when the sea grape is fully ripe, or during the month of June. The numbers of these Pigeons that resort to the Keys, attract several species of Hawks during the breeding season, amongst which the Peregrine and the Red-shouldered are conspicuous. On none of the Keys unvisited by this species, did I see a Hawk of any kind.

The White-headed Pigeon exhibits little of the pomposity of the common domestic species, in its amorous moments. The male, however, struts before the female with elegance, and the tones of his voice are quite sufficient to persuade her of the sincerity of his attachment. During calm and clear mornings, when nature appears in all her purity and brightness, the cooing of this Pigeon may be heard at a considerable distance, mingling in full concord with the softer tones of the Zenaida Dove. The bird standing almost erect, full-plumed, and proud of his beauty, emits at first a loud croohoo, as a prelude, and then proceeds to repeat his coo-coo-coo. These sounds are continued during the period of incubation, and are at all times welcome to the ear of the visiter of these remarkable islands. When approached suddenly, it emits a hollow, guttural sound, precisely resembling that of the Common Pigeon on such occasions.

The young birds are at first almost black, but have tufts of a soft buffcoloured down distributed mostly over the head and shoulders. While yet squabs they have no appearance of white on the head, and they take about four months before they acquire their perfect plumage. Smaller size, and a less degree of brilliancy, distinguish the female from the male. About the beginning of October they abound on the Keys, and return to the West India Islands.

I have only to add the following particulars to what I have already detailed of the history of this species. While standing perched in a nearly 
upright posture, they have a continued movement of the head, with a frequent jerking upwards of the tail. Their flight may be compared to that of the European Cushat, being very swift and noiseless, after a few hard flaps at starting. In captivity they are easily managed, and readily breed. I saw several of them with my friends Dr. Wilson and Rev. Jоно Bachman of Charleston, South Carolina.

The White-headed Pigeon does not occur to the westward of the Florida Keys on the shores of the Gulf of Mexico; at least I have seen none in any portion of all that extensive range of country as far as Galveston Island in Texas. The eggs of this species measure one inch and two and a half eighths in length, an inch and half an eighth in breadth; although in more than fifty instances I found two eggs in each nest, the Earl of DERBY informs me that in captivity, like Columba migratoria, this Pigeon lays only one.

I have placed a pair of these Pigeons on a low, flowering tree, which is rather scarce on the Keys. It is in full bloom during the whole year, and its leaves, I thought, correspond with the colour of the birds, while the brilliant hue of its flowers forms a strong contrast.

\section{Columba leucocephala, Bonap. Syn., p. 119.}

White-headed Pigeon, Columba leucocephala, Bonap. Amer. Orn., vol. ii. p. 15.

White-crowned Pigeon, Nutt. Man., vol. i. p. 625.

White-headed Pigeon, Columba leucocephala, Aud. Orn. Biog., vol. ii. p. 443; vol. v. p. 557 .

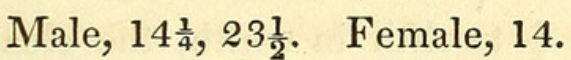

Florida Keys. Common during summer only.

Adult Male.

Bill straight, of ordinary length, rather slender, compressed; upper mandible with a tumid fleshy covering at the base, where it is straight in its dorsal outline, convex towards the end, with a sharp-edged, declinate, rather obtuse tip; lower mandible with the sides sloping outwards, the angle near the end, the edges sharp, the tip rounded. Nostrils medial, oblique, linear. Head small and compressed, neck of ordinary length, body full. Feet short, strong; tarsus very short, rounded, with two anterior rows of large hexagonal scales; toes scutellate above, marginate, the hind-toe smallest, the two lateral nearly equal, the middle toe much larger; claws of moderate size, compressed, arched, rather acute.

Plumage rather compact above, blended beneath, on the hind neck strong, with metallic gloss. Wings long, the third quill longest, the second almost equal, the first not so long as the fourth, the second, third, fourth, and most of the other primaries sinuate on the outer web, towards the end; the 
secondaries broad and rounded. Tail rather long, even, of twelve broad slightly rounded feathers.

Bill carmine at the base, bluish-white at the end. Iris yellow. Feet carmine; claws greyish-yellow. The general colour is dusky greyish-blue, paler beneath, the quills and tail-feathers darker. The whole upper part of the head is pure white; the upper part of the hind neck rich chocolate-brown, the lower part and sides green, changing to gold-colour, each feather margined externally with deep black.

Length $14 \frac{1}{4}$ inches, extent of wings $23 \frac{1}{2}$; bill along the back $\frac{8}{12}$, along the edge $\frac{11}{12}$; tarsus $1 \frac{1}{12}$, middle-toe and claw $1 \frac{11}{12}$.

Adult Female.

The female differs from the male only in having the tints a little duller and lighter.

In a specimen preserved in spirits, the interior of the mouth is similar to that of the Passenger Pigeon; as is the tongue, which is 8 twelfths long, but broader towards the end than in that species. The œsophagus is 5 inches 9 twelfths long; its width at the upper part nearly 1 inch; the crop of the same form and structure as in the species above named, and nearly of the same size. The stomach is $1 \frac{1}{2}$ inches in breadth, $1 \frac{1}{4}$ inches in length; its muscles very strong, the left 6 twelfths, the right 7 twelfths thick; the epithelium of a horny texture, with two concave grinding surfaces. It contains seeds of fruits. The intestine is 28 inches long: the duodenum is 6 twelfths in breadth; the average width of the rest of the intestine is 3 twelfths. The cœca are $2 \frac{1}{2}$ twelfths long, $\frac{1}{2}$ twelfth in width; the cloaca very little dilated, its width about 9 twelfths.

The trachea is $4 \frac{1}{4}$ inches long, from 3 twelfths to $2 \frac{1}{4}$ twelfths in breadth; the rings extremely feeble, unossified on the back part, and 90 in number; the last ring of the same form as in the other species, and the muscles are similar. Bronchi moderate, of about 15 half rings.

The brain in these Pigeons is proportionally much smaller than in any other bird examined, excepting the Goat-suckers and Cuckoos.

The Rough-Leaved Cordia.

Cordia sebestena, Willd.-Pentandria Monogynia, Linn.-Cordiacee, Juss.

This plant, on account of its large tubular scarlet flowers, is one of the most beautiful of the West Indian trees. I saw only two individuals at Key West, where, as was supposed, they had been introduced from Cuba. They were about fifteen feet high, the stem having a diameter of only five or six 

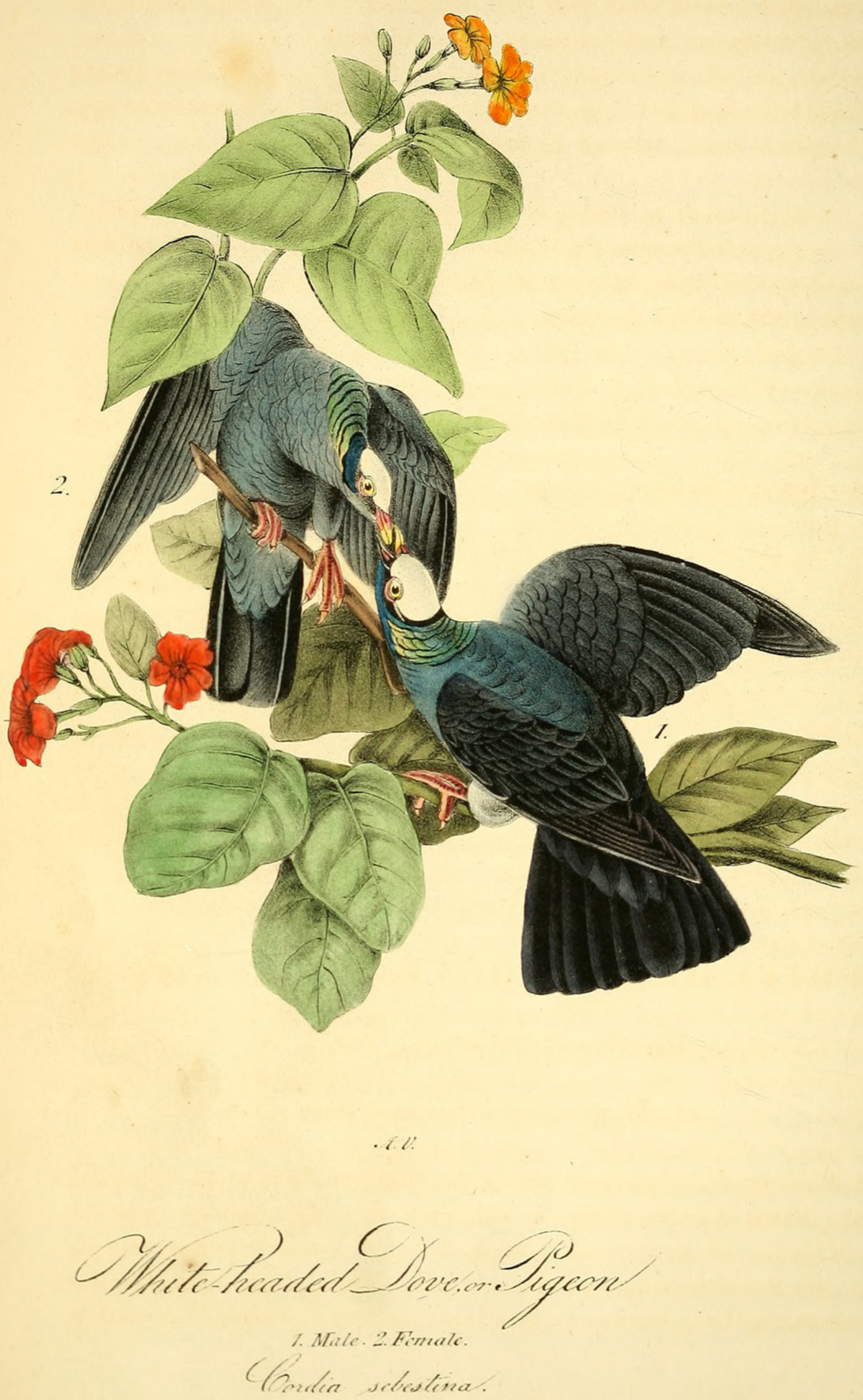


\section{$2 \mathrm{BHL}$ Biodiversity Heritage Library}

Audubon, John James. 1842. "White-Headed Dove, or Pigeon, Columba leucocephala, Linn. [PI. 280]." The birds of America: from drawings made in the United States and their territories 4, 315-320. https://doi.org/10.5962/p.319395.

View This Item Online: https://www.biodiversitylibrary.org/item/125069

DOI: https://doi.org/10.5962/p.319395

Permalink: https://www.biodiversitylibrary.org/partpdf/319395

\section{Holding Institution}

Smithsonian Libraries

\section{Sponsored by}

Biodiversity Heritage Library

\section{Copyright \& Reuse}

Copyright Status: NOT_IN_COPYRIGHT

This document was created from content at the Biodiversity Heritage Library, the world's largest open access digital library for biodiversity literature and archives. Visit BHL at https://www.biodiversitylibrary.org. 